\title{
CURRENT THERAPEUTIC OPTIONS FOR CORONAVIRUS DISEASE-2019 - A PHARMACOLOGICAL REVIEW
}

\author{
SASMI MB ${ }^{1}$, MARIA JOSE ${ }^{1 *}$, PRAVEENLAL KUTTICHIRA ${ }^{2}$ \\ ${ }^{1}$ Department of Pharmacology, Jubilee Mission Medical College and Research Institute, Thrissur, Kerala, India. ${ }^{2}$ Department of Psychiatry, \\ Jubilee Mission Medical College and Research Institute, Thrissur, Kerala, India.*Email: mariarinkujos@gmail.com
}

Received: 12 May 2020, Revised and Accepted: 10 June 2020

\section{ABSTRACT}

Objectives: Coronavirus pandemic is currently a global public health emergency. With expanding knowledge of the virus and the disease, new therapeutic targets are emerging widely. There is limited evidence about the use of different treatment options in coronavirus disease-2019 (COVID-19). This review aims to summarize the available evidence regarding therapeutic options in treating coronavirus infection.

Methods: We searched PubMed, Google Scholar, and Cochrane library using pre-specified Medical Subject Headings terms about the role of therapeutic options in COVID-19 patients.

Results: The majority of the published evidence is either case reports or small observational studies. Antimalarial like hydroxychloroquine reported equivocal results with five studies got positive results and five without any added benefit compared with standard of care. Lopinavir/ ritonavir monotherapy does not show any significant role except in combination with other antiviral drugs but encouraging results are emerging with remdesivir. Studies with favipiravir are inconclusive with some exhibit benefit and others not. Limited case series have shown that tocilizumab and convalescent plasma to be useful as adjuvant therapy in critically ill patients.

Conclusion: There is currently no strong evidence for the efficacy of different therapeutic agents in the treatment of COVID-19. More data from ongoing and future trials will add more insight into the role of various drugs.

Keywords: Coronavirus disease-2019, Severe acute respiratory syndrome-coronavirus-2, Coronavirus, Drug treatment.

(C) 2020 The Authors. Published by Innovare Academic Sciences Pvt Ltd. This is an open access article under the CC BY license (http://creativecommons. org/licenses/by/4. 0/) DOI: http://dx.doi.org/10.22159/ajpcr.2020.v13i8.38342

\section{INTRODUCTION}

We all came across firstly a severe acute respiratory syndrome (SARS)-like flu or influenza spreading across China in numbers, which was monumental. What started from a wet market from Wuhan China, soon spread beyond physical and geopolitical boundaries reaching farflung countries and taking its toll. What is more terrifying is that we are ill whipped both materialistically and scientifically to combat this pandemic. As per the WHO coronavirus situation reports on May 10, globally there are 4,179,479 confirmed cases of coronavirus disease (COVID-19) and 287,525 deaths [1]. In India, the toll remains as 74,281 confirmed cases and 2415 deaths so far [1].

Scientists identified 2019 novel coronavirus (2019-nCoV) in samples of bronchoalveolar lavage fluid from a patient in Wuhan. The WHO named the disease officially as COVID-19 on February 11, 2020. COVID-19 characterized by respiratory syndrome with a variable degree of severity, ranging from a mild upper respiratory tract illness to severe interstitial pneumonia and acute respiratory distress syndrome (ARDS) [2,3]. 2019$\mathrm{nCoV}$ (also called SARS-CoV-2) is a single-stranded RNA virus coming under the same genus beta coronavirus as SARS coronavirus 1 (SARS-CoV-1) and Middle East respiratory syndrome coronavirus (MERS-CoV) [4]. SARS-CoV-2 binds angiotensin-converting enzyme 2 (ACE2), which is an ectoenzyme anchored to the plasma membrane of the cells of several tissues like respiratory cells. SARS-induced down-regulation of ACE2 receptors in lung epithelium contributes to the pathogenesis of acute lung injury and subsequent ARDS.

There is no specific antiviral treatment recommended for COVID-19, and no vaccine is currently available. The treatment is symptomatic, and oxygen therapy represents the major treatment intervention for patients with severe infection. Mechanical ventilation, high-flow nasal oxygen or non-invasive ventilation, and extracorporeal membrane oxygenation (ECMO) are among other strategies, which vary on case to case. There have been few studies on coronaviruses and the effective antiviral therapies that the world at large is ignorant and at an emergent time to scuttle all the available research to battle up on coronavirus.

With expanding knowledge of the virus and the disease, new therapeutic targets are emerging day by day. However, so far, published evidence is less. Many clinical trials are also ongoing worldwide. In this review, we tried to combine all the available evidence in literature and researches to get an overall knowledge of the current therapeutic options for COVID-19.

\section{METHODS}

We prepared a study protocol and predefined the data sources, search strategy, study eligibility criteria, and data extraction of the studies.

\section{Data sources and search strategies}

We searched for clinical studies providing data on the efficacy of different therapeutic agents COVID-19 infection, restricting the search to English articles. We searched PubMed, Google Scholar, and Cochrane library using the Medical Subject Headings terms: "Chloroquine (CQ)," "Hydroxychloroquine (HCQ)," "Lopinavir," "Ritonavir," "Remdesivir," "Favipiravir (FPV)" "immunoglobulins or Convalescent plasma or hyperimmune immunoglobulins" "Tocilizumab (TCZ)" and "COVID-19," "SARS-CoV-2," and "treatment” published through May 10, 2020.

\section{Study selection}

Two independent reviewers systematically searched the literature using the pre-specified strategy. We included the abstracts, original articles, pre-proofs of the accepted article, pre-prints, case reports or 
case series, and letter to the editor published until May 10, 2020, which investigated or discussed the role of different therapeutic agents in COVID-19 infection. We searched the reference lists of identified articles to identify further relevant articles. We used systematic reviews as a point of reference. We excluded in-vitro studies and studies published in languages other than English.

\section{Data extraction}

The data from selected articles were studied independently by two investigators (SMB and MJ), and the consensus was achieved with mutual discussion. The data extracted from full-length articles wherever available. We included abstracts only when they had sufficient data. We extracted the following information from the included studies: Year of study, the country where the study was conducted, study population, intervention, comparisons (if applicable), study designs, sample size, the study objective/s, duration of the study, primary endpoints and outcomes in terms of virological load, disease progression, radiological progression, intensive care units (ICU) admission, mean length of hospital stay, and mortality. We present the findings in the form of a table and narrative summaries.

\section{RESULTS}

At present, no therapeutic drugs are available that are directly active against SARS-CoV-2. Antimalarials such as CQ HCQ, and several antivirals such as lopinavir/ritonavir (LPVr), remdesivir, FPV, and biologics (convalescent plasma and monoclonal antibodies) have emerged as potential therapies.
Table 1 summarizes the mechanism of action and major pharmacologic parameters of select proposed treatments or adjunctive therapies for COVID-19.

Agents previously used to treat similar respiratory viruses; SARS-CoV and MERS-CoV are potential candidates to treat COVID-19. We summarize clinical experiences of some of the most promising repurposed drugs we reviewed for COVID-19 by drug-class.

\section{Antimalarials}

$H C Q$ and $C Q$

Some preliminary studies have shown that HCQ has significant in vitro activity against SARS-CoV-2, providing the rationale for its use in the treatment and prevention of COVID-19 infection [16]. Studies have shown, HCQ to be more potent against SARS-CoV-2 than CQ [17]. In our review, we found ten studies using HCQ and three studies using CQ (Table 2).

The study by Gautret et al. [18] showed significantly higher virus clearance rate at 6-day post-inclusion in HCQ group compared with standard-of-care with added benefit on the addition of azithromycin. This same group from France reported results from an observational study that reported good clinical outcomes, but there was no comparison group and most patients had a low National Early Warning Score [19]. In contrast, a randomized study [20] showed no impact of HCQ on virological clearance and clinical resolution in patients with mild to moderate COVID-19 infection. In another randomized trial [21] published as preprint version (not peer-reviewed), the patients on HCQ

Table 1: Pharmacologic therapies considered for the treatment of COVID-19

\begin{tabular}{|c|c|c|c|}
\hline Drug class & Mechanism of action & Adverse effects & $\begin{array}{l}\text { Current } \\
\text { recommendations }\end{array}$ \\
\hline $\begin{array}{l}\text { Chloroquine } \\
\text { hydroxychloroquine } \\
{[5-8]}\end{array}$ & $\begin{array}{l}\text { Blocks viral entry into cells by inhibiting } \\
\text { glycosylation of host receptors, proteolytic } \\
\text { processing, and endosomal acidification } \\
\text { Immunomodulatory effects are through } \\
\text { attenuation of cytokine production and inhibition }\end{array}$ & $\begin{array}{l}\text { Risk of cardiac arrhythmias (e.g., QTc } \\
\text { prolongation) } \\
\text { Risk of retinal damage on long-term use } \\
\text { Caution in patients with G6PD deficiency, } \\
\text { diabetics, and neuropsychiatric disorders }\end{array}$ & $\begin{array}{l}\text { On March 28, 2020, the } \\
\text { US FDA approved CQ and } \\
\text { HCQ for emergency use } \\
\text { in hospitalized COVID-19 } \\
\text { patients }\end{array}$ \\
\hline
\end{tabular}

Lopinavr/Ritonavir Ritonavir act as a pharmacokinetic booster $[9,10] \quad$ for Lopinavir. Both drugs bind and inhibit SARS-CoV main protease (Mpro), also called 3-chymotrypsin-like protease (3CLpro) which plays a crucial role in processing the viral RNA

Remdesivir [5] Investigational nucleoside analog and prodrug of remdesivir triphosphate. It acts as an inhibitor of RNA-dependent RNA polymerases and incorporated into the viral RNA at the position I, terminates RNA synthesis at position $\mathrm{i}+3$

Favipiravir [11,12] Investigational agent

Favipiravir converted into an active phosphoribosylated form in cells and inhibits viral RNA-dependent RNA polymerase, causing chain termination and preventing RNA elongation

Tocilizumab [13,14] A monoclonal antibody that inhibits IL-6mediated signaling

IL-6 is a pro-inflammatory cytokine Cytokine release syndrome may be a component of severe disease in COVID-19

Convalescent plasma Antibodies from recovered COVID-19 patients (hyperimmune immunoglobulins) [15] may help with both free virus and infected cell immune clearance. Earlier used as salvage therapy in SARS and MERS
Risk of cardiac arrhythmias (QTc prolongation), especially along with CQ, azithromycin, etc.

Gastrointestinal disturbances (diarrhea, pancreatitis), hepatotoxicity

Significant drug-drug interaction (CYP450 enzyme inhibitor)

Nausea, vomiting, gastroparesis, hematochezia, elevation in hepatic aminotransferase

Mild GI intolerance, hyperuricemia, liver injury

Risk of GI perforation

Increase in hepatic transaminase levels

Caution in patients with thrombocytopenia

and neutropenia

Infusion-related reactions

Inadvertent infection with another infectious Not approved by US FDA pathogen

Transfusion-associated circulatory overload, and transfusion-associated acute lung injury Potential worsening of immune-mediated tissue damage
US FDA approved drug but not for COVID-19

On May 1, 2020, the US FDA granted emergency use authorization of remdesivir for the treatment of confirmed COVID-19 Not approved by the US FDA.

Not approved by the US FDA.

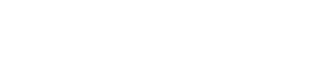


Table 2: Clinical studies of HCQ and CQ in patients with COVID-19

\begin{tabular}{|c|c|c|}
\hline $\begin{array}{l}\text { Author/country/ } \\
\text { sample size }\end{array}$ & Study design/intervention & Results \\
\hline $\begin{array}{l}\text { Gautret et al. } \\
\text { France } \\
\mathrm{n}=36[18]\end{array}$ & $\begin{array}{l}\text { Prospective open label, non- } \\
\text { randomized trial } \\
\text { HCQ }(n=14) \text {, HCQ + azithromycin } \\
(n=6) \text { versus control group }(n=20)\end{array}$ & $\begin{array}{l}\text { Virological clearance (day 6): } 70.0 \% \text { (HCQ) versus } 12.5 \%(\text { control) }(\mathrm{p}=0.001) \\
\text { Virological clearance }(\text { day } 6): \text { HCQ plus azithromycin }(100 \%), \text { HCQ monotherapy } \\
(57.1 \%) \text {, and control arm }(12.5 \%)(p<0.001)\end{array}$ \\
\hline $\begin{array}{l}\text { Chen et al. } \\
\text { China } \\
\mathrm{n}=30[20]\end{array}$ & $\begin{array}{l}\text { Randomized control trial } \\
\text { HCQ + standard of care }(n=15) \\
\text { versus control group }(n=15)\end{array}$ & $\begin{array}{l}\text { Virological clearance (day 7): } 86.7 \% \text { (HCQ) versus } 93.3 \% \text { (control) }(\mathrm{p}>0.05) \\
\text { Median time for virological clearance: } 4(1-9) \text { days (HCQ) versus } 2(1-4) \text { days } \\
\text { (control) (p>0.05) } \\
\text { Fever recovery time: } 1(0-2)(\mathrm{HCQ}) \text { versus } 1(0-3) \text { (control) }(\mathrm{p}>0.05) \\
\text { Mild adverse events reported in } 4 / 15(26.7 \%) \text { of HCQ group and } 3 / 15(20 \%) \text { of } \\
\text { control group }\end{array}$ \\
\hline $\begin{array}{l}\text { Chen et al. } \\
\text { China } \\
\mathrm{n}=62[21]\end{array}$ & $\begin{array}{l}\text { Randomized control trial } \\
\text { HCQ+standard of care }(n=31) \text { versus } \\
\text { control group }(n=31)\end{array}$ & $\begin{array}{l}\text { Fever recovery time: } 2.2(0.4) \text { days }(\mathrm{HCQ}) \text { versus } 3.2(1.3) \text { days }(\text { control) }(\mathrm{p}<0.05) \\
\text { Cough recovery time: } 2 \text { days (HCQ) versus } 3.1 \text { days }(\text { control) }(\mathrm{p}<0.05) \\
\text { Chest CT improvement: } 80.6 \%(\mathrm{HCQ}) \text { versus } 54.8 \% \text { (control) }(\mathrm{p}<0.05) \\
\text { Mild adverse events reported in } 2 / 31 \text { patients who received HCQ. }\end{array}$ \\
\hline $\begin{array}{l}\text { Gautret et al.. France } \\
n=80[19]\end{array}$ & $\begin{array}{l}\text { Prospective observational study } \\
\text { HCQ and azithromycin } \\
\text { No comparator }\end{array}$ & $\begin{array}{l}\text { Virological clearance (day } 7 \text { ): } 83 \% \text { and } 93 \% \text { at Day } 8 \\
\text { Mortality - 1/80; ICU patients - } 3 / 80 \\
\text { Mean length of hospital stay - } 5 \text { days }\end{array}$ \\
\hline $\begin{array}{l}\text { Molina et al. } \\
\text { France } \\
\mathrm{n}=11[23] \\
\text { Million } \text { et al. } \\
\text { France } \\
\mathrm{n}=1061[24]\end{array}$ & $\begin{array}{l}\text { Prospective observational study } \\
\text { HCQ and azithromycin } \\
\text { No comparator } \\
\text { Observational study } \\
\text { HCQ and azithromycin } \\
\text { No comparator }\end{array}$ & $\begin{array}{l}\text { Nasopharyngeal swab positive: } 8 / 10 \text { patients } 5-6 \text { days after treatment initiation } \\
\text { Mortality } 1 / 11 \text {; ICU admission: } 2 / 11 \\
\text { Therapy discontinued in } 1 \text { patient due to QT prolongation } \\
\text { Virological clearance (day } 10): 91.7 \% \\
\text { Poor clinical outcome: } 46 / 1061(4.3 \%) \text { patients } \\
\text { Mortality: } 8 / 1061(0.75 \%) \\
\text { The poor clinical outcome associated with } \\
\text {-Older age (OR } 1.11 \text { ) } \\
\text {-Initial higher severity (OR 10.05) } \\
\text {-Low HCQ serum concentration. } \\
\text { No cardiac toxicity observed. }\end{array}$ \\
\hline $\begin{array}{l}\text { Mahevas et al. France } \\
\mathrm{n}=84[25]\end{array}$ & $\begin{array}{l}\text { Observational study (routine care } \\
\text { data) } \\
\text { HCQ (n=84) } \\
\text { Comparator (non HCQ group) } \\
\text { (n=97) }\end{array}$ & $\begin{array}{l}\text { ICU admission (within } 7 \text { days) : } \\
\text { 20.2\% (HCQ group) versus 22.1\% (no-HCQ group) (relative risk [RR] 0.91, 95\% } \\
\text { CI: } 0.47-1.80 \text { ) } \\
\text { Mortality (within } 7 \text { days): } 2.8 \% \text { (HCQ group) versus } 4.6 \% \text { (no-HCQ group) (RR } \\
0.61,95 \% \text { CI: } 0.13-2.89 \text { ) } \\
\text { ARDS (within } 7 \text { days): } 27.4 \% \text { (HCQ group) versus } 24.1 \% \text { (no-HCQ group) (RR } \\
\text { 1.14, 95\% CI: } 0.65-2.00 \text { ) } \\
\text { Adverse events: } 9.5 \% \text { experienced electrocardiogram modifications requiring } \\
\text { HCQ discontinuation }\end{array}$ \\
\hline $\begin{array}{l}\text { Magagnoli et al. } \\
\text { United States } \\
\mathrm{n}=368[26]\end{array}$ & $\begin{array}{l}\text { Retrospective study } \\
\text { HCQ (n=97), HCQ+azithromycin } \\
(n=113), \text { no HCQ }(n=158)\end{array}$ & $\begin{array}{l}\text { Rates of death: } \\
\text { HCQ (27.8\%), HCQ+azithromycin }(22.1 \%) \text {, no HCQ groups }(11.4 \%) \text { (adjusted } \\
\text { hazard ratio, } 2.61 ; 95 \% \text { CI, } 1.10 \text { to } 6.17 ; \mathrm{p}=0.03) \\
\text { Rates of ventilation: HCQ }(13.3 \%), \mathrm{HCQ}+\text { azithromycin }(6.9 \%) \text {, and no HCQ groups } \\
(14.1 \%) \text { (adjusted hazard ratio, } 1.43 ; 95 \% \mathrm{CI}, 0.53 \text { to } 3.79 ; \mathrm{p}=0.48)\end{array}$ \\
\hline $\begin{array}{l}\text { Geleris } \text { et al. } \\
\text { United States } \\
n=1446 \\
1376 \text { assessed [27] }\end{array}$ & $\begin{array}{l}\text { Observational study } \\
\text { HCQ }(n=811) \\
\text { non HCQ }(n=565)\end{array}$ & $\begin{array}{l}\text { Composite endpoint of intubation or death: } 25.1 \% \text { in HCQ group } \\
\text { No significant association between HCQ use and intubation or death (hazard ratio, } \\
1.04,95 \% \text { confidence interval, } 0.82 \text { to } 1.32 \text { ) }\end{array}$ \\
\hline $\begin{array}{l}\text { Gao et al. } \\
\text { China } \\
\mathrm{n}=100[28] \\
\text { Huang et al. } \\
\text { China } \\
\mathrm{n}=22[29]\end{array}$ & $\begin{array}{l}\text { Randomized control trial } \\
\text { CQ versus control } \\
\text { Randomized control trial } \\
\text { CQ }(n=10) \text { versus LPVr }(n=12)\end{array}$ & $\begin{array}{l}\text { CQ found to be superior in reducing symptom duration, exacerbation of } \\
\text { pneumonia, and promoting virus-negative seroconversion without any severe side } \\
\text { effects (details not yet published) } \\
\text { CQ was slightly superior to LPVr in terms of virological clearance on } \\
\text { day } 7 \text {, day } 10 \text {, and day } 14 \text { post-treatment. CQ improved the radiological } \\
\text { appearance of the lungs (by day } 14 \text {, the rate ratio was } 2.21,95 \% \mathrm{CI}: 0.81-6.62 \text { ) } \\
\text { and decreased the hospital stay }\end{array}$ \\
\hline $\begin{array}{l}\text { Borba et al. } \\
\text { Brazil } \\
\mathrm{n}=81[30]\end{array}$ & $\begin{array}{l}\text { Double-blinded, randomized, phase } \\
\text { IIb clinical trial two arms: high dose } \\
\text { CQ ( } 600 \mathrm{mg} \text { twice daily for } 10 \text { days) } \\
\text { and low dose CQ ( } 450 \mathrm{mg} \text { for } 5 \text { days) } \\
\text { All received azithromycin and } \\
\text { ceftriaxone }\end{array}$ & $\begin{array}{l}\text { High dosage CQ arm - } 18.9 \% \text { had QTc }>500 \mathrm{~ms} \text { and the trend toward higher } \\
\text { lethality (39\%) than the lower dosage arm. } \\
\text { Fatality rate until day } 13-27 \% \text { ( } 95 \% \text { CI: } 17.9-38.2 \% \text { ) in high dose arm }\end{array}$ \\
\hline
\end{tabular}

n: Total number of patients, p: Significant level, CI: Confidence interval, CRP: C reactive protein, CQ: Chloroquine, HCQ: Hydroxychloroquine, LPVr: Lopinavir/ritonavir 
improved clinically in terms of fever recovery time, cough remission time, and radiological improvement. In another open-label, randomized, and controlled trial from China [22] (released as a preprint), the patients on HCQ had a slight benefit in resolution in symptoms, when controlling for receipt of antivirals, but no benefit was seen in virological clearance.

A study by Molina et al. [23] reported persistence of SARS-CoV-2 in the nasopharyngeal swab in 8 of 10 patients who had other significant co-morbidities. In an observational study in 1061 patients [24], the majority obtained virological clearance by day 10 and poor clinical outcome was associated with older age, initial higher severity, and low HCQ serum concentration. Results from another study (also from France) [25] released as a preprint, do not support the use of HCQ in patients hospitalized with SARS-CoV-2-positive hypoxic pneumonia, and noted that seven (out of 84) patients developed QTc prolongation. A retrospective analysis done in the United States [26], the risk for death was higher in the HCQ group than in the non-HCQ group (adjusted hazard ratio with HCQ versus without, 2.6). A recent observational study from the US involving hospitalized COVID-19 patients concluded that HCQ administration was not associated with either a greatly lowered or an increased risk of the composite endpoint of intubation or death [27].

CQ was superior in reducing symptom duration, exacerbation of pneumonia, and promoting virus-negative seroconversion without any severe side effects in two randomized trials from China [28,29]. In a double-blind, randomized trial from Brazil [30], the higher-dose CQ arm discontinued as per a data safety monitoring board for increased mortality. A Cochrane review protocol to evaluate the effect of CQ and HCQ on the treatment of COVID-19 had published and results are awaiting [31].

\section{Antivirals (Table 3)}

$L P V r$

LPVr is an FDA approved fixed-dose combination used for the treatment of human immunodeficiency virus (HIV). Preliminary studies demonstrated in vitro activity against SARS-CoV-1 and MERS-CoV; both are closely related to SARS-CoV-2 [32]. A recent study reported that LPVr inhibits SARS-CoV-2 replication in Vero E6 cells with half-maximal effective concentration (EC50) under $100 \mu \mathrm{M}$ [33]. Earlier in vivo, human evidence published were mainly individual case reports and clinical series. Many clinical trials are ongoing, with results expected in near future.

LOTUS trial (Table 3), which compared LPVr with standard-of-care, no benefit seen with LPVr treatment beyond standard care in terms of clinical improvement or viral load [34]. In ELACOI Trial [35], (released as pre-print) LPVr and arbidol monotherapy compared with the control group and they found little benefit for improving the clinical outcome or in virological conversion over supportive care. In both these trials, severely or critically affected patients were not included in the study.

Yan et al. [36] found that virological clearance is more in LPVr treated patients and Ye et al. [37] demonstrated LPVr combination treatment has a more evident clinical improvement with no evident toxic side effects compared with adjuvant drugs alone. Deng et al. [38] also compared arbidol and LPVr combination with LPVr monotherapy and found the apparent favorable clinical response and virological clearance with arbidol and LPVr combination over LPVr monotherapy.

In two published clinical series [39,40] from China reported clinical improvement and speedy virological clearance in COVID-19 pneumonia after administration of LPVr. Another case series from Singapore [41] reported only an equivocal clinical benefit with supportive care. Two different case reports from Korea and China [42,43] reported significantly decreased viral load and clinical as well as a radiological improvement after the administration of LPVr.

\section{Remdesivir}

Remdesivir is an investigational nucleoside analog, developed for the treatment of Ebola. As an experimental drug, remdesivir will not be available for treating a large population and obtained only via compassionate use, expanded access, or enrolment in a clinical trial.

In vitro data found that remdesivir exerts potent antiviral activity against a clinical isolate of SARS-CoV-2 (EC50 $=0.77 \mathrm{mcg}$, half-cytotoxic concentration [CC50] $>100 \mathrm{mcg}$, selective index [SI] >129.87). Data suggest remdesivir inhibits the activity of 2002 SARS-CoV, MERS-CoV, and bat $\mathrm{CoV}$ strains that can replicate in human epithelial cells and mediate entry through human $\mathrm{CoV}$ receptors. Remdesivir has shown prophylactic and therapeutic efficacy against 2002 SARS-CoV in a mouse model $[5,44]$.

In the United States, the first patient with COVID-19 has shown significant improvement in clinical symptoms within $24 \mathrm{~h}$ of treatment with remdesivir [45]. In a Clinical series by Kujawski et al., following remdesivir initiation all patients improved, even though they had transient gastrointestinal symptoms [46]. In a cohort [47], of patients hospitalized for severe COVID-19 treated with compassionate-use remdesivir, 36 of 53 patients (68\%) showed clinical improvement.

A multicentre trial carried out at ten hospitals in Hubei China [48] compared the effects of remdesivir with placebo in severe COVID-19. Patients permitted for concomitant use of other antiviral drugs also. They concluded that remdesivir was not associated with statistically significant clinical benefits or antiviral effects. Clinical trials [49] are ongoing to evaluate the safety and antiviral activity of remdesivir in patients with mild to moderate or severe COVID-19.

\section{FPV/favilavir}

FPV is an investigational nucleosideanaloglicensed in Japan and China for the treatment of influenza. FPV effectively inhibits the SARS-CoV-2 infection in Vero E6 cells [5].

A multicentre trial [50] conducted to compare the efficacy of FPV and arbidol, another anti-influenza drug approved in China and Russia. They observed that FPV associated with significantly shortened latency to relief for pyrexia and cough, it does not significantly improve clinical recovery. Cai et al. [51] compared the clinical outcomes between patients who treated with FPV and LPVr and reported that FPV showed better treatment outcomes in COVID-19 patients in terms of their disease progression and viral clearance than LPVr.

\section{Other antiviral agents}

Interferon (IFN)

IFN- $\alpha$ is a broad-spectrum antiviral agent that is usually used to treat hepatitis and it is reported to inhibit SARS-CoV reproduction in vitro. Antiviral effects had demonstrated in animal models also [52]. Even though in vitro activity against SARS-CoV2 has been reported [53], human data are limited as IFN often evaluated in combination with other drugs and make it difficult to decipher whether the effect is due to IFN alone. Various combinations of ribavirin, IFN, and other antiviral agents are currently studying in several clinical trials.

\section{Ribavirin}

Ribavirin is a nucleoside analog with broad-spectrum antiviral effects. The synergistic antiviral effect between ribavirin and IFN was also described [52]. However, in vitro activity [5] against SARS-CoV-2 is far less, along with a lack of human data apart from combination therapy and high toxicity makes ribavirin a less promising agent in the treatment of COVID-19.

\section{Oseltamivir}

Oseltamivir is a neuraminidase inhibitor approved for the treatment of influenza. There is no documented data suggesting in vitro activity against SARS-CoV -2. In the early phases of the COVID, 19 outbreaks in China oseltamivir have been widely used as empirical treatment [54], but to date, there is no evidence for its effectiveness. 
Table 3: Clinical studies of antiviral drugs in patients with COVID-19

\begin{tabular}{|c|c|}
\hline $\begin{array}{l}\text { Author/country/ } \\
\text { sample size }\end{array}$ & Study design/intervention \\
\hline $\begin{array}{l}\text { Lopinavir/Ritonavir } \\
\text { Cao et al } \\
\text { China } \\
n=199[34]\end{array}$ & $\begin{array}{l}\text { Randomized, controlled, open- } \\
\text { label trial (LOTUS Trial) } \\
\text { LPVr + standard care }(n=99) \\
\text { standard-care alone }(n=100)\end{array}$ \\
\hline $\begin{array}{l}\text { Li et al } \\
\text { China } \\
n=86[35]\end{array}$ & $\begin{array}{l}\text { Exploratory randomized }(2: 2: 1) \\
\text { controlled trial (ELACOI trial) } \\
\text { LPVr group }(n=34) \\
\text { Arbidol group }(n=35) \\
\text { Control group with no antiviral } \\
\text { medication }(n=17)\end{array}$ \\
\hline $\begin{array}{l}\text { Yan et al } \\
n=120[36]\end{array}$ & $\begin{array}{l}\text { Observational study } \\
\text { LPVr treatment group }(n=78) \\
\text { Control group not treated with } \\
\text { LPVr }(n=42)\end{array}$ \\
\hline $\begin{array}{l}\text { Ye et al } \\
\text { China } \\
n=47 \text { [37] }\end{array}$ & $\begin{array}{l}\text { Observational study } \\
\text { Test group treated with LPVr }+ \\
\text { adjuvant medicines }(n=42) \\
\text { Control group, only adjuvant } \\
\text { medicine }(n=5)\end{array}$ \\
\hline $\begin{array}{l}\text { Deng et al } \\
\text { China } \\
n=33[38]\end{array}$ & $\begin{array}{l}\text { Observational study } \\
\text { Arbidol+LPVrcombination group } \\
(n=16) \\
\text { LPVr monotherapy group }(n=16)\end{array}$ \\
\hline
\end{tabular}

Remdesivir Yeming et al

China $n=236[48]$

\section{Result}

Time to clinical improvement between the two arms (16 days in both groups; hazard ratio 1.31; 95\% CI: 0.95-1.85; p=0.09)

Mortality at 28 days: $19.2 \%$ (LPVr) versus 25\% (control) (difference, -5.8 percentage points; 95\% CI, -17.3-5.7)

Patients with detectable viral RNA at various time points were similar in both groups Gastrointestinal adverse events were more common in the LPVr group and treatment discontinued in 13 patients $(13.8 \%)$ because of adverse events

Meantime for the positive-to-negative conversion of SARS-CoV-2 nucleic acid: 9.0 days (SD 5.0) in the LPVr group, 9.1 (SD 4.4) in the arbidol group, and 9.3 (SD 5.2) in the control group $(\mathrm{p}=0.981)$

The rates of antipyresis, cough alleviation, or improvement of chest CT at days 7 or 14: all $\mathrm{p}>0.05$

Deterioration in clinical status from moderate to severe/critical: At day 7, eight $(23.5 \%)$ patients in the LPVr group, three $(8.6 \%)$ in arbidol group, and two $(11.8 \%)$ in the control group with $\mathrm{p}=0.206$

Safety outcome: 12 (35.3\%) patients in the LPVr group and five

$(14.3 \%)$ in the arbidol group

Virological clearance: The median duration of viral shedding the LPV/r treatment group versus control group - median, 22 days versus 28.5 days, $(\mathrm{p}=0.02)$. Only earlier administration of LPVr treatment ( $\leq 10$ days from symptom onset) could shorten the duration of viral shedding

Fever recovery: Test group: $4.8 \pm 1.94$ days versus control group: $7.3 \pm 1.53$ days, $\mathrm{p}=0.0364$

Virological clearance: Test group: $7.8 \pm 3.09$ days versus control group: $12.0 \pm 0.82$ days, $\mathrm{p}=0.0219$

Virological clearance: Negative in $12(75 \%)$ of 16 in the combination group after 7 days compared with $6(35 \%)$ of 17 in the monotherapy group $(\mathrm{p}<0 \cdot 05)$. After 14 days, 15 $(94 \%)$ of 16 and $9(52 \cdot 9 \%)$ of 17 , respectively, with $p<0 \cdot 05$.

Radiological improvement: 11 (69\%) of 16 patients in the combination group after 7 days, compared with $5(29 \%)$ of 17 in the monotherapy group $(\mathrm{p}<0 \cdot 05)$

Randomized, double-blind, placebo-controlled, multicentre trial (2:1)

Remdesivir group $(\mathrm{n}=158)$

Placebo group $(\mathrm{n}=78)$

The time to clinical improvement: 21.0 days (interquartile range, IQR 13.0-28.0) (remdesivir) versus 23.0 days (15.0-28.0) (control)

Hazard ratio 1.23 (95\% CI 0.87-1.75)

28-day mortality: (22 [14\%] (remdesivir) versus 10 [13\%] (placebo) difference 1·1\% [95\% CI 8.1-10.3]).

Virological clearance (day 28): 153 (78\%) of 196 patients and the negative proportion was similar among patients receiving remdesivir and placebo

Adverse events: 102 (66\%) of 155 remdesivir recipients versus 50 (64\%) of 78 placebo recipients.

Treatment discontinued: Remdesivir in 18 (12\%) patients versus four (5\%) in placebo

Favipiravir

Chen et al.

China

$\mathrm{n}=240[50]$
Prospective, randomized, controlled, open-label multicenter trial FPV group ( $\mathrm{n}=120), 116$ assessed Arbidol group $(\mathrm{n}=120)$

$\begin{array}{ll}\begin{array}{l}\text { Cai et al. } \\ \text { China }\end{array} & \text { Open label non randomized } \\ n=80[51] & \text { controlled study } \\ & \text { FPV group }(n=35) \\ & \text { LPVr group }(n=45)\end{array}$

Clinical improvement: FPV group versus arbidol group-71/116 versus 62/120 ( $p=0.1396$, difference of recovery rate: $0.0954 ; 95 \%$ CI: $-0.0305-0.2213$ ) Fever recovery and cough relief: FPV led to shorter latencies to relief for both pyrexia (difference: 1.70 days, $\mathrm{p}<0.0001$ ) and cough (difference: 1.75 days, $\mathrm{p}<0.0001$ ). No difference was observed of AOT or NMV rate (both $\mathrm{p}>0.05$ )

Safety outcome: FPV-associated adverse event was raised serum uric acid (16/116, OR: $5.52, \mathrm{p}=0.0014$ )

Virological clearance: The FPV arm versus the control arm - median (interquartile range, IQR), 4 (2.5-9) days versus 11 (8-13) days, $p<0.001$

Radiological improvement after $14^{\text {th }}$ day: The FPV arm versus the control arm, $91.43 \%$ versus $62.22 \%(\mathrm{p}=0.004)$

The total number of adverse events in the FPV arm versus control arm - $4(11.43 \%)$ versus $25(55.56 \%)$ with $(<0.001)$

n: Total number of patients, LPVr: Lopinavir/ritonavir, CI: Confidence interval, SD: Standard deviation, p: Significant level, FPV: Favipiravir, AOT: Auxiliary oxygen therapy, NMV: Noninvasive mechanical ventilation

\section{Arbidol/umifenovir}

Arbidol is a broad-spectrum antiviral drug act by inhibiting cell entry of enveloped viruses by blocking viral fusion with the host cell membrane and approved in China and Russia for the treatment of influenza [55]. Even though it is shown in vitro activity against many
DNA and RNA viruses, there is no data to support in vitro activity against SARS-CoV-2. Many trials and observational studies compared arbidol and other antiviral drugs with hopeful results [35,38,50]. However, published data for monotherapy as well as availability are limited. 


\section{Biologics}

Immunoglobulins/convalescent plasma/hyperimmune immunoglobulins

The rationale to use convalescent COVID-19 antibody-positive plasma to treat persons with active COVID-19 is based on the prior experience treating SARS-CoV-1 and MERS-CoV. A systematic review by Mair-Jenkins et al. of eight observational studies including 714 patients with SARS showed administration of convalescent plasma was associated with a reduction in mortality (odds ratio, 0.25 [95\% CI, $0.14-0.45]$ ]) with relatively few harms [15]. In theory, the benefits of this therapy would occur primarily within the first 7-10 days of infection, when viremia is at its peak and the primary immune response has not yet occurred. Limited data are available from five small case series (combined 28 patients) [56-60] reported from China have provided initial encouraging results. These patients were critically ill patients with ARDS or at an early stage of clinical deterioration or in ventilators. Clinical symptoms and paraclinical criteria improved shortly after the administration of plasma. No obvious adverse effects observed during the treatment of these patients. The use of convalescent plasma had not studied in pregnancy, though one of the patients in a small case series of four critically ill patients was pregnant [60]

\section{TCZ}

A subset of persons with COVID-19 develops a massive inflammatory response that can result in ARDS, multi-organ failure, and potentially death [14]. This massive systemic inflammatory response is characterized as a cytokine storm and with very high levels of IL6, thereby suggesting IL-6 may play a central role in the acute clinical decompensation. TCZ by competitive inhibition of IL-6 could potentially diminish this massive systemic inflammatory response in these patients. There are limited data from uncontrolled studies about the potential benefit of TCZ in patients with COVID-19.

In a prospective observational study in China [61], TCZ was added to standard care in 21 patients with severe COVID-19. Patients who received TCZ had reduced oxygen requirement, normalization of the C-reactive protein (CRP), and decreased lymphocytopenia. All these patients were also treated with an antiviral (LPVr) and methylprednisolone. A retrospective study from China [62], involving 15 moderate to critically ill COVID-19 patients, TCZ improved CRP in all patients, but 3 of 4 critically ill patients died despite therapy. These four critically ill patients experienced persistent elevations in IL-6 levels. A prospective, single-arm multicenter study [63] on off-label use of TCZ, a significant improvement in the levels of ferritin, CRP, and D-dimer has seen 63 hospitalized adult patients with severe COVID-19. The overall mortality was $11 \%$ and TCZ administration within 6 days from admission in the hospital was associated with an increased likelihood of survival (hazard ratio 2.2 95\% CI 1.3-6.7, p<0.05). Many case reports show improvement with a single dose of TCZ in critically ill patients with comorbidities such as liver transplant, sickle cell disease, hemodialysis, systemic sclerosis, and multiple myeloma [64-69]. In a case series of two patients with COVID-19 induced cytokine release syndrome and elevated IL-6 levels progressed to secondary hemophagocytic lymphohistiocytosis despite treatment with TCZ and one developed viral myocarditis challenging the safety and clinical utility of the drug [70].

\section{Miscellaneous drugs}

\section{Corticosteroids}

Corticosteroids act as immunomodulatory agents and no in vitro studies were found on the cytopathic effect of corticosteroids alone against SARS-CoV. The data assessing the role of corticosteroids as adjunctive care for severe coronavirus (SARS-CoV-1, MERS-CoV, and SARS-CoV-2) pneumonia is difficult to interpret because of significant heterogeneity about the timing of administration and dose of steroids use [52]. Potential side effects such as delayed viral clearance and secondary infections warrant the use of steroids on a risk-benefit assessment in individual patients. Russell et al. [71] recommend that corticosteroids should not be used in 2019-nCoV-induced lung injury or shock, except in the setting of a clinical trial.

\section{Ivermectin and nitazoxanide}

Both agents are FDA-approved commercial antiparasitic drugs which shown to have in vitro activity against SARS-CoV-2 [5,72]. However, published evidence is limited and clinical trials need to be conducted to confirm the effectiveness in humans with COVID-19.

\section{Angiotensin converting enzyme inhibitors (ACEIs) and angiotensin receptor blockers (ARBs)}

As coronaviruses bind to their target cells through ACE2, ACEIs or ARBs may have a protective effect in COVID-19. Initial speculation was that ACEIs or ARBs may increase ACE2 expression and this will be harmful in SARS-CoV-2 infection, while recent studies $[73,74]$ shown that the use of ARBs or ACEs is not associated with an increased risk of acquiring SARS-CoV-2 infection. Data are insufficient to evaluate the effects of ACEIs or ARBs in COVID-19. Multiple trials are underway on this purpose, including recombinant human ACE2 and the ARB losartan in COVID-19.

\section{DISCUSSION}

Considering antimalarials, five studies showed positive results in terms of virological clearance and resolution of clinical symptoms whereas five studies showed no added benefit in the HCQ group compared with standard of care. These studies have significant limitations. The study by Gautret et al. [18] had a small sample size and was nonrandomized. Moreover, their evaluation was purely microbiological and not clinical. In the trial conducted by Chen et al. [20], concomitant antivirals were given to the patients, which might have served as confounders when interpreting the results some studies only included patients with mild disease and so it is not possible to extrapolate these results to critically ill patients [21]. Beyond these concerns about efficacy, CQ and HCQ are not without toxicity, of particular concern is QTc prolongation due to these agents. One meta-analysis [75] done on treatment effects of HCQ in COVID-19 infection showed treatment with HCQ resulted in less number of cases showing the radiological progression of lung disease (odds ratio 0.31, 0.11-0.9) whereas no difference was observed in virological cure (odds ratio 2.37, 0.13-44.53) when compared to the control/conventional treatment.

Among the direct antiviral drugs, LPVr was used very widely in China during the early phase of the outbreak, and many cases reports shown encouraging results. The two clinical trials conducted on LPVr depicted that LPVr is not superior to the standard treatments. The LOTUS trial was non-blinded as well as they did not take account of concurrent pharmacological treatment [34] Even though some of the observational studies yield positive results [36-38], it is difficult to generalize the results of these studies as the sample size is too small and their endpoints are narrow and limited. Their retrospective nature also contributes to the chance of missing many details, which hinders the generalization. Extrapolation of results to critically ill patients is also difficult as different hospitals differently classified the patients based on the evidence. LPVr monotherapy does not show any significant role in the treatment of COVID-19 except in combination with other antiviral drugs and leads to minimal use in many countries. It is too early to disregard the drug as a potential target. In all of the existing case-series and case-reports, antiviral agents were used in combination with other medications, and therefore the observed outcomes cannot be solely attributed to antiviral therapy.

On the other part, remdesivir is emerging as a promising agent in COVID-19 treatment due to its potent in vitro activity and favorable case reports. It has been administered to 700 patients with confirmed, severe SARS-CoV-2 infections in the United States, Europe, and Japan through Expanded Access or Compassionate Use programs and yielding encouraging results [76]. The small size of the cohort and the relatively short follow-up period, limit the interpretation of the study. Even though the only clinical trial published establishes no significant benefit for remdesivir over placebo, there are more trials ongoing and expecting breakthrough results. Studies on FPV are limited and inconclusive with 
one trial establishing no superiority over comparator. Other antiviral drugs do not earn a recommendation for monotherapy other than empirical or combination treatment.

The limited sample size and study design preclude a definitive statement about the potential effectiveness of convalescent plasma transfusion. It may be helpful in the treatment of critically ill patients with COVID-19 and ARDS. The optimal dose and time point, as well as the clinical benefit of convalescent plasma therapy, need further investigation in larger well-controlled trials. Although TCZ is not FDA-approved for the treatment of COVID-19, the established efficacy with the treatment of cytokine release syndrome has provided a rationale for its use in the treatment of COVID-19 as adjunctive therapy. Current phase III trials will be crucial in understanding the place in therapy of TCZ as a supportive care option in alleviating the severe respiratory symptoms associated with COVID-19 [77]. ECMO could be considered as effective rescue therapy for the patients having respiratory distress [78]. Regarding the anti-parasitic drugs as well as ACEIs and ARBs, more controlled studies are needed to arrive at a conclusive point

According to the Indian council for medical research (ICMR) guidelines [79], HCQ in combination with azithromycin is recommended in patients with severe disease and patients requiring ICU management, under close medical supervision with monitoring side effects. Depending on local epidemiological data and risk factors empirical therapy with a neuraminidase inhibitor is suggested, provided de-escalation of treatment on microbiology results. Routine use of corticosteroids is not recommended outside clinical trials unless they are indicated for other reasons. Recently, ICMR researchers published a protocol restricted use of LPVr in symptomatic COVID-19 patients [80]. The apex body also approved a clinical trial of convalescent plasma for COVID-19 in multiple centers.

\section{Limitations}

Our review is not short on limitations. Newer evidence is flooding on a day-to-day basis owing that the views and recommendations can be changing. This review is based on available case reports, series, retrospective observational studies, and very few clinical trials. In addition, we only selected articles written in English because we did not have the resources available to translate potential articles written in various other languages.

\section{CONCLUSIONS}

There is currently no strong evidence for the efficacy of different therapeutic agents in the treatment of COVID-19. Overall, the limited studies identified were subject to methodological flaws and some available in only non-peer-reviewed preprints. The majority of the existing articles have used concurrent treatments such as antibiotics, immunoglobulin, IFN, and glucocorticoids in their studies. Hence, the reports presented cannot be attributed solely to targeted drugs.

\section{AUTHORS' CONTRIBUTIONS}

All the authors have contributed to the collection of articles, preparation, and editing of the manuscript.

\section{CONFLICTS OF INTEREST}

There are no conflicts of interest.

\section{REFERENCES}

1. Coronavirus Disease (COVID-19) Situation Reports. Available from: https://www.who.int/emergencies/diseases/novel-coronavirus-2019/ situation-reports. [Last accessed on 2020 May 13].

2. Chen N, Zhou M, Dong X, Qu J, Gong F, Han Y, et al. Epidemiological and clinical characteristics of 99 cases of 2019 novel coronavirus pneumonia in Wuhan, China: A descriptive study. Lancet 2020;395:507-13.

3. Kumari VB, Patil SM, Shirahatti PS, Sujay S, Tejaswini M, Ranganatha LV, et al. The current status and perspectives for the emerging pandemic: COVID-19. Int J Pharm Pharm Sci 2020;12:38206.
4. Chen Y, Liu Q, Guo D. Emerging coronaviruses: Genome structure, replication, and pathogenesis. J Med Virol 2020;92:418-23.

5. Wang M, Cao R, Zhang L, Yang X, Liu J, Xu M, et al. Remdesivir and chloroquine effectively inhibit the recently emerged novel coronavirus (2019-nCoV) in vitro. Cell Res 2020;30:269-71.

6. Zhou D, Dai SM, Tong Q. COVID-19: A recommendation to examine the effect of hydroxychloroquine in preventing infection and progression. J Antimicrob Chemother 2020;75:1667-70.

7. Devaux CA, Rolain JM, Colson P, Raoult D. New insights on the antiviral effects of chloroquine against coronavirus: What to expect for COVID-19? Int J Antimicrob Agents 2020;55:105938.

8. Kalil AC. Treating COVID-19-off-label drug use, compassionate use, and randomized clinical trials during pandemics. JAMA 2020;323:1897-8.

9. Nutho B, Mahalapbutr P, Hengphasatporn K, Pattaranggoon NC, Simanon N, Shigeta Y, et al. Why are lopinavir and ritonavir effective against the newly emerged coronavirus 2019? Atomistic insights into the inhibitory mechanisms. Biochemistry 2020;59:1769-79.

10. Zhang L, Lin D, Sun X, Curth U, Drosten C, Sauerhering L, et al. Crystal structure of SARS-CoV-2 main protease provides a basis for the design of improved alpha-ketoamide inhibitors. Science 2020;368:409-12.

11. Dong L, Hu S, Gao J. Discovering drugs to treat coronavirus disease 2019 (COVID-19). Drug Discov Ther 2020;14:58-60.

12. Furuta Y, Komeno T, Nakamura T. Favipiravir (T-705), a broadspectrum inhibitor of viral RNA polymerase. Proc Jpn Acad Ser B Phys Biol Sci 2017;93:449-63.

13. Sebba A. Tocilizumab: The first interleukin-6-receptor inhibitor. Am J Health Syst Pharm 2008;65:1413-8.

14. Zhang C, Wu Z, Li JW, Zhao H, Wang GQ. Cytokine release syndrome in severe COVID-19: Interleukin-6 receptor antagonist tocilizumab may be the key to reduce mortality. Int J Antimicrob Agents 2020;55:105954.

15. Mair-Jenkins J, Saavedra-Campos M, Baillie JK, Cleary P, Khaw FM, Lim WS, et al, Convalescent Plasma Study Group. The effectiveness of convalescent plasma and hyperimmune immunoglobulin for the treatment of severe acute respiratory infections of viral etiology: A systematic review and exploratory meta-analysis. J Infect Dis 2015;211:80-90

16. Liu J, Cao R, Xu M, Wang X, Zhang H, Hu H, et al. Hydroxychloroquine, a less toxic derivative of chloroquine, is effective in inhibiting SARSCoV-2 infection in vitro. Cell Discov 2020;6:16.

17. Yao X, Ye F, Zhang M, Cui C, Huang B, Niu P, et al. In vitro antiviral activity and projection of optimized dosing design of hydroxychloroquine for the treatment of severe acute respiratory syndrome Coronavirus 2 (SARS-CoV-2). Clin Infect Dis 2020;71:732-9.

18. Gautret P, Lagier JC, Parola P, Hoang VT, Meddeb L, Mailhe M, et al. Hydroxychloroquine and azithromycin as a treatment of COVID-19: Results of an open-label non-randomized clinical trial. Int J Antimicrob Agents 2020;56:105949.

19. Gautret P, Lagier JC, Parola P, Hoang VT, Meddeb L, Sevestre J, et al. Clinical and microbiological effect of a combination of hydroxychloroquine and azithromycin in 80 COVID-19 patients with at least a six-day follow up: A pilot observational study. Travel Med Infect Dis 2020;34:101663.

20. Chen J, Liu D, Liu L, Liu P, Xu Q, Xia L, et al. A pilot study of hydroxychloroquine in treatment of patients with moderate COVID-19. J Zhejiang Univ 2020;49:215-9.

21. Chen Z, Hu J, Zhang Z, Jiang S, Han S, Yan D, et al. Efficacy of hydroxychloroquine in patients with COVID-19: Results of a randomized clinical trial. MedRxiv 2020; [Preprint].

22. Tang W, CaoZ, Han M, Wang Z, Chen J, Sun W, et al. Hydroxychloroquine in patients with mainly mild to moderate coronavirus disease 2019: Open label, randomised controlled trial. BMJ 2020;369:m1849.

23. Molina JM, Delaugerre C, Le Goff J, Mela-Lima B, Ponscarme D, Goldwirt L, et al. No evidence of rapid antiviral clearance or clinical benefit with the combination of hydroxychloroquine and azithromycin in patients with severe COVID-19 infection. Med Mal Infect 2020;50:384

24. Million M, Lagier JC, Gautret P, Colson P, Fournier PE, Amrane S, et al. Early treatment of COVID-19 patients with hydroxychloroquine and azithromycin: A retrospective analysis of 1061 cases in Marseille, France. Travel Med Infect Dis 2020;35:101738.

25. Mahevas M, Tran VT, Roumier M, Chabrol A, Paule R, Guillaud C, et al. No evidence of clinical efficacy of hydroxychloroquine in patients hospitalized for COVID-19 infection with oxygen requirement: Results of a study using routinely collected data to emulate a target trial. MedRxiv 2020; [Preprint]

26. Magagnoli J, Narendran S, Pereira F, Cummings TH, Hardin JW, Sutton SS, et al. Outcomes of Hydroxychloroquine Usage in United 
States Veterans Hospitalized with COVID-19; 2020. Available from: http://www.sciencedirect.com/science/article/pii/S2666634020300064.

27. Geleris J, Sun Y, Platt J, Zucker J, Baldwin M, Hripcsak G, et al. Observational study of hydroxychloroquine in hospitalized patients with covid-19. N Engl J Med 2020;382:2411-8.

28. Gao J, Tian Z, Yang X. Breakthrough: Chloroquine phosphate has shown apparent efficacy in treatment of COVID-19 associated pneumonia in clinical studies. Biosci Trends 2020;14:72-3.

29. Huang M, Tang T, Pang P, Li M, Ma R, Lu J, et al. Treating COVID-19 with chloroquine. J Mol Cell Biol 2020;12:322-5.

30. Borba MG, Val FF, Sampaio VS, Alexandre MA, Melo GC, Brito M, et al. Effect of high vs low doses of chloroquine diphosphate as adjunctive therapy for patients hospitalized with severe acute respiratory syndrome coronavirus 2 (SARS-CoV-2) infection: A randomized clinical trial. JAMA Netw Open 2020;3:e208857.

31. Singh B, Ryan H, Kredo T, Chaplin M, Fletcher T. Chloroquine or hydroxychloroquine for prevention and treatment of COVID-19. Cochrane Database Syst Rev 2020;4:CD013587.

32. Yao TT, Qian JD, Zhu WY, Wang Y, Wang GQ. A systematic review of lopinavir therapy for SARS coronavirus and MERS coronavirus-a possible reference for coronavirus disease-19 treatment option. J Med Virol 2020;92:556-63.

33. Choy KT, Wong AY, Kaewpreedee P, Sia SF, Chen D, Hui KP, et al. Remdesivir, lopinavir, emetine, and homoharringtonine inhibit SARSCoV-2 replication in vitro. Antiviral Res 2020;178:104786.

34. Cao B, Wang Y, Wen D, Liu W, Wang J, Fan G, et al. A trial of lopinavirritonavir in adults hospitalized with severe covid-19. N Engl J Med 2020;382:1787-99.

35. Li Y, Xie Z, Lin W, Cai W, Wen C, Guan Y, et al. An exploratory randomized, controlled study on the efficacy and safety of lopinavir/ ritonavir or arbidol treating adult patients hospitalized with mild/ moderate COVID-19 (ELACOI). MedRxiv 2020; [In press].

36. Yan D, Liu XY, Zhu YN, Huang L, Dan BT, Zhang GJ, et al. Factors associated with prolonged viral shedding and impact of lopinavir/ ritonavir treatment in hospitalised non-critically ill patients with SARSCoV-2 infection. Eur Respir J 2020;56:2000799.

37. Ye XT, Luo YL, Xia SC, Sun QF, Ding JG, Zhou Y, et al. Clinical efficacy of lopinavir/ritonavir in the treatment of coronavirus disease 2019. Eur Rev Med Pharmacol Sci 2020;24:3390-6.

38. Deng L, Li C, Zeng Q, Liu X, Li X, Zhang H, et al. Arbidol combined with LPV/r versus LPV/r alone against corona virus disease 2019: A retrospective cohort study. J Infect 2020;81:e1-5.

39. Wang Z, Chen X, Lu Y, Chen F, Zhang W. Clinical characteristics and therapeutic procedure for four cases with 2019 novel coronavirus pneumonia receiving combined Chinese and Western medicine treatment. Biosci Trends 2020;14:64-8.

40. Liu F, Xu A, Zhang Y, Xuan W, Yan T, Pan K, et al. Patients of COVID-19 may benefit from sustained lopinavir-combined regimen and the increase of eosinophil may predict the outcome of COVID-19 progression. Int J Infect Dis 2020;95:183-91.

41. Young BE, Ong SW, Kalimuddin S, Low JG, Tan SY, Loh J, et al, Singapore 2019 Novel Coronavirus Outbreak Research Team. Epidemiologic features and clinical course of patients infected with SARS-CoV-2 in Singapore. JAMA 2020;323:1488-94.

42. Lim J, Jeon S, Shin HY, Kim MJ, Seong YM, Lee WJ, et al. Case of the index patient who caused tertiary transmission of COVID-19 infection in Korea: The application of lopinavir/ritonavir for the treatment of COVID-19 infected pneumonia monitored by quantitative RT-PCR. J Korean Med Sci 2020;35:e79.

43. Han WZ, Quan B, Guo Y, Zhang J, Lu Y, Feng G, et al. The course of clinical diagnosis and treatment of a case infected with coronavirus disease 2019. J Med Virol 2020;92:461-3

44. Agostini ML, Andres EL, Sims AC, Graham RL, Sheahan TP, Lu X, et al. Coronavirus susceptibility to the antiviral remdesivir (GS-5734) is mediated by the viral polymerase and the proofreading exoribonuclease. mBio 2018;9:e0221-18

45. Holshue ML, DeBolt C, Lindquist S, Lofy KH, Wiesman J, Bruce H, et al, Washington State 2019-nCoV Case Investigation Team. First case of 2019 novel coronavirus in the United States. N Engl J Med 2020;382:929-36

46. Kujawski S, Wong K, Collins J, Epstein L, Killerby M, Midgley C, et al. First 12 patients with coronavirus disease 2019 (COVID-19) in the United States. MedRxiv 2020; [Preprint]

47. Grein J, Ohmagari N, Shin D, Diaz G, Asperges E, Castagna A, et al. Compassionate use of remdesivir for patients with severe covid-19. N Engl J Med 2020;382:2327-36

48. Wang Y, Zhang D, Du G, Du R, Zhao J, Jin Y, et al. Remdesivir in adults with severe COVID-19: A randomised, double-blind, placebocontrolled, multicentre trial. Lancet 2020;395:1569-78.

49. Available from: https://www.clinicaltrials.gov. [Last accessed on 2020 Apr 25].

50. Chen C, Huang J, Cheng Z, Wu J, Chen S, Zhang Y, et al. Favipiravir versus arbidol for COVID-19: A randomized clinical trial. MedRxiv 2020; [Preprint].

51. Cai Q, Yang M, Liu D, Chen J, Shu D, Xia J, et al. Experimental treatment with favipiravir for COVID-19: An open-label control study. Engineering (Beijing) 2020; [In press].

52. Stockman LJ, Bellamy R, Garner P. SARS: Systematic review of treatment effects. PLoS Med 2006;3:e343.

53. Lu H. Drug treatment options for the 2019-new coronavirus (2019nCoV). Biosci Trends 2020;14:69-71.

54. Haviernik J, Stefanik M, Fojtikova M, Kali S, Tordo N, Rudolf I, et al. arbidol (umifenovir): A broad-spectrum antiviral drug that inhibits medically important arthropod-borne flaviviruses. Viruses 2018;10:184.

55. Mantlo E, Bukreyeva N, Maruyama J, Paessler S, Huang C. Antiviral activities of Type I interferons to SARS-CoV-2 infection. Antiviral Res 2020;179:104811.

56. Shen C, Wang Z, Zhao F, Yang Y, Li J, Yuan J, et al. Treatment of 5 critically ill patients with COVID-19 with convalescent plasma. JAMA 2020;323:1582-9.

57. Cao W, Liu X, Bai T, Fan H, Hong K, Song H, et al. High-dose intravenous immunoglobulin as a therapeutic option for deteriorating patients with coronavirus disease 2019. Open Forum Infect Dis 2020;7:ofaa102.

58. Duan K, Liu B, Li C, Zhang H, Yu T, Qu J, et al. Effectiveness of convalescent plasma therapy in severe COVID-19 patients. Proc Natl Acad Sci U S A 2020;117:9490-6.

59. Ye M, Fu D, Ren Y, Wang F, Wang D, Zhang F, et al. Treatment with convalescent plasma for COVID-19 patients in Wuhan, China. J Med Virol 2020;4:1-12

60. Zhang B, Liu S, Tan T, Huang W, Dong Y, Chen L, et al. Treatment with convalescent plasma for critically ill patients with severe acute respiratory syndrome Coronavirus 2 infection. Chest 2020;158:e9-13.

61. Xu X, Han M, Li T, Sun W, Wang D, Fu B, et al. Effective treatment of severe COVID-19 patients with tocilizumab. Proc Natl Acad Sci U S A 2020;117:10970-5

62. Luo P, Liu Y, Qiu L, Liu X, Liu D, Li J. Tocilizumab treatment in COVID-19: A single center experience. J Med Virol 2020;92:814-8.

63. Sciascia S, Aprà F, Baffa A, Baldovino S, Boaro D, Boero R, et al. Pilot prospective open, single-arm multicentre study on off-label use of tocilizumab in patients with severe COVID-19. Clin Exp Rheumatol 2020;38:529-32.

64. Odièvre $\mathrm{MH}$, de Marcellus $\mathrm{C}$, Le Pointe HD, Allali S, Romain AS, Youn J, et al. Dramatic improvement after tocilizumab of severe COVID-19 in a child with sickle cell disease and acute chest syndrome. Am J Hematol 2020;5:E192-4.

65. Hammami MB, Garibaldi B, Shah P, Liu G, Jain T, Chen PH, et al. Clinical course of COVID-19 in a liver transplant recipient on hemodialysis and response to tocilizumab therapy: A case report. Am J Transplant 2020;5:1-6.

66. Ferrey AJ, Choi G, Hanna RM, Chang Y, Tantisattamo E, Ivaturi K, et al. A case of novel coronavirus disease 19 in a chronic hemodialysis patient presenting with gastroenteritis and developing severe pulmonary disease. Am J Nephrol 2020;51:337-42.

67. Michot JM, Albiges L, Chaput N, Saada V, Pommeret F, Griscelli F, et al. Tocilizumab, an anti-IL-6 receptor antibody, to treat COVID-19related respiratory failure: A case report. Ann Oncol 2020;31:961-4.

68. Mihai C, Dobrota R, Schröder M, Garaiman A, Jordan S, Becker MO, et al. COVID-19 in a patient with systemic sclerosis treated with tocilizumab for SSc-ILD. Ann Rheum Dis 2020;79:668-9.

69. Zhang X, Song K, Tong F, Fei M, Guo H, Lu Z, et al. First case of COVID-19 in a patient withmultiple myeloma successfully treated with tocilizumab. Blood Adv 2020;4:1307-10.

70. Radbel J, Narayanan N, Bhatt PJ. Use of tocilizumab for COVID-19induced cytokine release syndrome: A cautionary case report. Chest 2020;158:e15-9.

71. Russell CD, Millar JE, Baillie JK Clinical evidence does not support corticosteroid treatment for 2019-nCoV lung injury. Lancet 2020;395:473-5

72. Caly L, Druce JD, Catton MG, Jans DA, Wagstaff KM. The FDAapproved drug ivermectin inhibits the replication of SARS-CoV-2 in vitro. Antivir Res 2020;178:104787.

73. Mancia G, Rea F, Ludergnani M, Apolone G, Corrao G. Reninangiotensin-aldosterone system blockers and the risk of covid-19. N Engl J Med 2020;382:2431-40. 
74. Mehra MR, Desai SS, Kuy S, Henry TD, Patel AN. Cardiovascular disease, drug therapy, and mortality in covid-19. N Engl J Med 2020;382:e102.

75. Sarma P, Kaur H, Kumar H, Mahendru D, Avti P, Bhattacharyya A, et al. Virological and clinical cure in covid-19 patients treated with hydroxychloroquine: A systematic review and meta-analysis. J Med Virol 2020;92:776-85.

76. Cao YC, Deng QX, Dai SX. Remdesivir for severe acute respiratory syndrome coronavirus 2 causing COVID-19: An evaluation of the evidence. Travel Med Infect Dis 2020;35:101647.

77. Alzghari SK, Acuña VS. Supportive treatment with tocilizumab for
COVID-19: A systematic review. J ClinVirol 2020;127:104380.

78. Divya SM, Thomas NV. Potential therapeutic avenues for COVID-19 therapy. Int J Pharm Pharm Sci 2020;2020:12.

79. Revised Guidelines on Clinical Management of COVID-19. Government of India Ministry of Health and Family Welfare Directorate General of Health Services (EMR Division); 2020. Available from: http://www.mohfw.gov.in. [Last accessed on 2020 May 13].

80. Bhatnagar T, Murhekar MV, Soneja M, Gupta N, Giri S, Wig N, et al. Lopinavir/ritonavir combination therapy amongst symptomatic coronavirus disease 2019 patients in India: Protocol for restricted public health emergency use. Indian J Med Res 2020;151:184-9. 